\title{
The role of systemic inflammatory indexes in predicting preeclampsia and its severity
}

\author{
Onur Bektaş (iD), Kıvılcım Bektaş (D), Cuma Taşın \\ Department of Obstetrics and Gynecology, Faculty of Medicine, Mersin University, Mersin, Turkey
}

\begin{abstract}
Objective: Abnormal changes in immune-mediated inflammation contribute to the pathogenesis of preeclampsia (PE). In our study, we aimed to investigate systemic inflammatory indexes [neutrophil/lymphocyte rate (NLR), platelet/lymphocyte rate (PLR), monocyte/ lymphocyte rate (MLR), platelet/neutrophil rate (PNR)] as disease markers as well as a theoretical basis for early diagnosis opportunity, evaluation of disease severity and prognosis of PE.
\end{abstract}

Methods: The records of 573 pregnant women were evaluated in this retrospective case-controlled study. Twenty-eight patients were excluded from the study as they suffered eclamptic seizure while 50 patients were excluded from the study due to HELLP syndrome (hemolysis, thrombocytopenia and elevated liver transaminases), 20 patients due to superimposed preeclampsia, 19 patients due to chronic hypertension and 25 patients due to gestational hypertension. Three groups were established where 190 patients were included in PE group, 119 patients in severe PE group and 122 healthy singleton pregnant women in the control group. Platelet numbers, neutrophil, monocyte and lymphocyte values as well as NLR, PLR, MLR and PNR values which are systemic inflammatory response markers of all groups were recorded and compared with each other.

Results: While no significant difference was found between PE and severe PE group, there was statistically significant difference in terms of the numbers of platelet, neutrophil, monocyte and lymphocyte numbers and NLR, PLR, MLR and PNR values when both PE groups were compared to the control group. When NLR is considered $>3.497$ for the control and PE groups, sensitivity is $51.5 \%$, specificity is $50.8 \%$, positive predictive value is $71.9 \%$, and negative predictive value is $71.4 \%$.

Conclusion: Secondary analyses of complete blood count parameters evaluate systemic inflammation and immunity effectively. According to the absolute leukocyte counts, NLR and PLR provide more effective markers in terms of clinical evaluation, and evaluation of PE severity and PE prognosis. However, with current findings, systemic inflammatory indexes are insufficient to establish preeclampsia diagnosis and to predict its severity.

Keywords: Preeclampsia, PLR, NLR, MLR, PNR.

\section{Özet: Sistemik inflamatuar indekslerin preeklampsiyi ve ciddiyetini öngörmedeki yeri}

Amaç: İmmün aracılı inflamasyondaki anormal değişiklikler preeklampsinin (PE) patogenezine katkıda bulunur. Bu çalışmada amacımız sistemik inflamatuar indekslerini [nötrofil/lenfosit oran (NLO), trombosit/lenfosit oranı (TLO), monosit/lenfosit oran (MLO), trombosit /nötrofil oranı (TNO)] hastalık göstergeleri olarak ve aynı zamanda erken tanı imkânı, hastalığın şiddetinin değerlendirilmesi ve PE'nin prognozu için teorik bir temel olarak araştırmaktır.

Yöntem: Retrospektif olgu kontrollü olarak planlanan bu çalışmada 573 gebenin klinik kayıtları tarandı. Yirmi sekiz hasta eklamptik nöbet geçirmesi, 50 hasta HELLP sendromu (hemoliz, trombositopeni ve yüksek karaciğer transaminaz), 20 hasta süperempoze preeklampsi, 19 hasta kronik hipertansiyon, 25 hasta gestasyonel hipertansiyonu olması nedeniyle çalışma dışına alındı. Yüz doksan hasta PE, 119 hasta şiddetli PE ve 122 săglıklı tekil gebe kontrol grubuna alınarak 3 grup oluşturuldu. Tüm grupların hemoglobin, trombosit sayısı, nötrofil, monosit, lenfosit değerleri ile birlikte sistemik inflamatuar yanıt belirteçleri olan NLO, TLO, MLO, TNO oranları kayıt altına alındı ve birbirleriyle karşılaştırild.

Bulgular: PE ve şiddetli PE grupları arasında anlamlı farklılık tespit edilmezken, her iki PE grubu kontrol grubuyla ayrı ayrı karşılaştırıldığında, trombosit, nötrofil, lenfosit ve monosit sayıları ile NLO, TLO, MLO ve TNO değerleri istatistiksel olarak anlamlı farklılık gösterdi. Kontrol ve PE grupları için NLO>3.497 olarak alındığında $\% 51.5$ sensitivite, $\% 50.8$ spesifisite, $\% 71.9$ pozitif prediktif değer, \%71.4 negatif prediktif değer elde edilmektedir.

Sonuç: Tam kan sayımı parametrelerinin sekonder analizleri sistemik inflamasyon ve bağışıklık durumunu etkin bir şekilde değerlendirmektedir. NLO ve TLO mutlak beyaz kan hücresi sayımlarına göre klinik değerlendirme, $\mathrm{PE}$ şiddetinin değerlendirilmesi ve PE'nin prognozunun değerlendirilmesi açısından daha etkili göstergeler sunar. Ancak hâlihazırdaki bulgularla sistemik inflamatuar indeksler preeklampsi tanısı koymada ve şiddetini öngörmede yeterli değildirler.

Anahtar sözcükler: Preeklampsi, TLO, NLO, MLO, TNO.

Correspondence: Onur Bektaş, MD. Department of Obstetrics and Gynecology, Faculty of Medicine, Mersin University, Mersin, Turkey. e-mail: o.b@outlook.com / Received: May 24, 2019; Accepted: September 2, 2019

Please cite this article as: Bektaş $\mathrm{O}$, Bektaş $\mathrm{K}$, Taşın $\mathrm{C}$. The role of systemic inflammatory indexes in predicting preeclampsia and its severity. Perinatal Journal 2019;27(2):62-67. doi:10.2399/prn.19.0272003 


\section{Introduction}

Hypertensive diseases complicate $5-11 \%$ of all pregnancies. Preeclampsia (PE) is an idiopathic multisystemic disease with unknown etiology affecting approximately $2-8 \%$ of pregnancies. ${ }^{[1]}$ It usually appear after 20 weeks of gestation and affects both mother and fetus which causes an increase in the rates of maternal and neonatal mortality and morbidity. PE is defined as the hypertension and proteinuria in a pregnant woman. In severe cases, PE may lead to maternal organ dysfunction, a systemic disease such as HELLP syndrome (hemolysis, thrombocytopenia and elevated liver transaminases), poor maternal outcomes and poor perinatal outcomes such as early and late intrauterine growth retardation. ${ }^{[2]}$ The main reasons of $\mathrm{PE}$ are not clear; however, recent studies have confirmed that $\mathrm{PE}$ is associated with extreme inflammation and abnormal immune responses. ${ }^{[3]}$

Hyperactivation of inflammatory and immunologic responses in preeclampsia causes a significant increase in neutrophil number and modulation of neutrophil function, and it leads to more superoxide production compared to nitric oxide, resulting in endothelial injury and dysfunction. ${ }^{[4-6]}$ Systemic immune inflammation indexes derived from peripheral blood cells have drawn attention recently because they are measured easily and practical. These combined indexes are calculated based on basic parameters such as platelet/lymphocyte rate (PLR), neutrophil/lymphocyte rate (NLR) and monocyte/lymphocyte rate (MLR). It is stated that they are diagnostically significant in many systemic and local inflammatory diseases such as coronary artery disease, diabetes mellitus, arthritis and ulcerative colitis, and that platelet/lymphocyte rate (PLR) in particular can be used as a marker for ovarian, colon and breast cancers. ${ }^{[7-12]}$ In PE, abnormal changes were also observed in leukocytes ${ }^{[13]}$ however, the role of these systemic inflammatory markers remains uncertain in clinical evaluation, differential diagnosis and prognosis evaluation in $\mathrm{PE}$.

$\mathrm{PE}$ is a progressive, unpredictable and untreatable disease, and its only treatment currently is the completion of pregnant in due course. Therefore, early diagnosis of PE is useful for the close clinical follow-up of the patients. In our study, we aimed to investigate systemic inflammatory indexes (NLR, PLR and MLR) as disease markers and also a theoretical basis for early diagnosis opportunity, evaluation of disease severity and the prognosis of PE.

\section{Methods}

After obtaining approval from Mersin University's Ethics Committee of Clinic Researches, 122 healthy pregnant women and 573 cases of whom 451 had hypertensive disease, who delivered in Department of Obstetrics and Gynecology, Faculty of Medicine, Mersin University which was a tertiary center between January 2010 and January 2019, were evaluated retrospectively. Twenty-eight patients were excluded from the study as they suffered eclamptic seizure while 50 patients were excluded from the study due to HELLP syndrome, 20 patients due to superimposed preeclampsia, 19 patients due to chronic hypertension and 25 patients due to gestational hypertension. The control group consisted of $122(28.3 \%)$ pregnant women who did not have maternal medical complication or autoimmune disease history and had normotensive singleton pregnancy during the same period. A total of 309 preeclampsia patients were separated into 2 groups as PE [190 (44.0\%)] and severe PE $[119(27.6 \%)]$. Complete blood count results of the cases sent as a routine practice before delivery, and hemoglobin $(\mathrm{Hb})(\mathrm{mg} / \mathrm{dl})$, neutrophil $\left(10^{3} / \mu \mathrm{L}\right)$, lymphocyte $\left(10^{3} / \mu \mathrm{L}\right)$, monocyte $\left(10^{3} / \mu \mathrm{L}\right)$ and platelet $\left(10^{3} / \mu \mathrm{L}\right)$ values were recorded. Thereafter, neutrophil/lymphocyte rate (NLR), platelet/lymphocyte rate (PLR), monocyte/lymphocyte rate (MLR) and platelet/neutrophil rate (PNR) were calculated and recorded.

Gestational age was calculated by evaluating last menstrual period and/or first trimester obstetric ultrasonography and the measurement of crown-rump length. Preeclamptic patient selection and classification were done according to the criteria of the study group established by American Congress of Obstetricians and Gynecologists in 2013. Accordingly, the diagnosis of preeclampsia was established through 2 measurements at least with 4-hour interval after 20 weeks of gestation where systolic blood pressure is $140 \mathrm{mmHg}$, diastolic blood pressure is $90 \mathrm{mmHg}$ and there is $300 \mathrm{mg}$ protein in 24-hour urine or the rate of protein $(\mathrm{mg} / \mathrm{dL}) /$ creatinine $(\mathrm{mg} / \mathrm{dL})$ is $\geq 0.3$ or it is at least +1 by dipstick while the case is normotensive before pregnancy. The diagnosis of severe preeclampsia was established by the presence of any of the following conditions: systolic blood pressure is $\geq 160 \mathrm{mmHg}$ and/or diastolic blood pressure is $\geq 110 \mathrm{mmHg}$, serum creatinine level is $>1.1 \mathrm{mg} / \mathrm{dL}$ or the concentration of serum creatinine is doubled without any renal disease or presence of new cerebral or visual disorders, pulmonary edema or thrombocytopenia 
(thrombocyte count $<100,000 / \mu \mathrm{L}$ ) or liver dysfunction (normal limits of liver enzyme levels doubling or elevating more than double), chronic severe right upper quadrant pain which cannot be explained by another diagnosis or presence of epigastric pain non-responsive to the treatment or presence of both conditions.

Data analysis was carried out by using IBM SPSS $\mathrm{v}$ 25.0 (Armonk, NY, USA). Conformity of the data to normal distribution was checked by KolmogorovSmirnov test. The data were presented as mean \pm standard deviation (SD) for continuous variable and as patient number (n) and percentage (\%) or median (minimum-maximum) for categorical variables. Chi-square test was used for the comparisons of categorical variables. Mann-Whitney test was performed to compare the nonparametric data between two groups and Kruskal-Wallis test was used to compare the data among three groups. ROC curves were created in PE group and the area under curve (AUC) was calculated for each marker (Fig. 1). Sensitivity, specificity and likelihood ratio were calculated according to the cut-off point determined by ROC curves. $\mathrm{p}<0.05$ was defined as statistically significant level.

\section{Results}

The cases included in the study were separated into three groups which were preeclampsia group ( $\mathrm{n}=190$; $44.0 \%)$, severe preeclampsia group ( $\mathrm{n}=119 ; 27.6 \%)$, and the control group ( $n=122 ; 28.3 \%)$; the ages of the cases varied between 18 and 46, and the mean age was $30.6 \pm 6.25$. The demographics of mothers and newborns are given in Table $\mathbf{1}$.

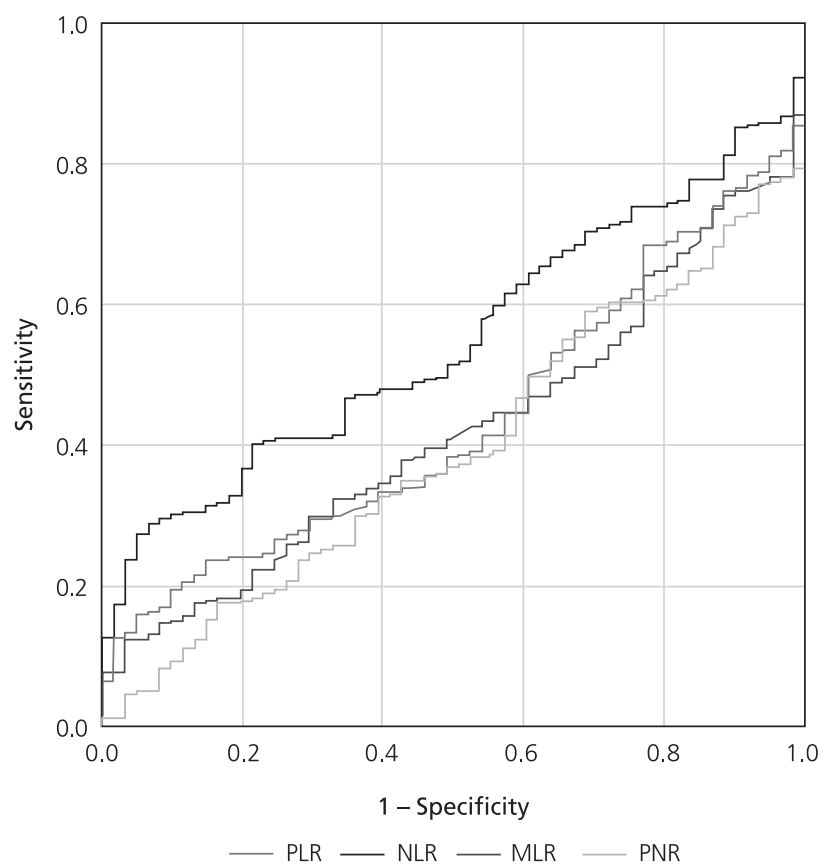

Fig. 1. ROC curves.

Statistically significant difference was found between the groups in terms of parity, number of living children, birth weights of newborns, week of gestation at delivery, and 1-minute and 5-minute Apgar scores $(\mathrm{p}<0.01)$. In severe preeclampsia group, 1-minute and 5-minute Apgar scores were significantly lower than the cases in both the control group and the preeclampsia group $(\mathrm{p} \leq 0.01, \mathrm{p}=0.022 ; \mathrm{p} \leq 0.01, \mathrm{p}=0.007)$. Compared to the control group, birth weights of newborns were significantly low in PE and severe PE groups $(\mathrm{p}=0.001$,

Table 1. Demographic information.

\begin{tabular}{|c|c|c|c|c|c|c|c|}
\hline & $\begin{array}{c}\text { PE } \\
(n=190 ; \\
\% 44.0) \\
\text { Mean+SD }\end{array}$ & $\begin{array}{c}\text { Severe PE } \\
(n=119 ; \\
\% 27.6) \\
\text { MeantSD }\end{array}$ & $\begin{array}{c}\begin{array}{c}\text { Control } \\
(n=122 ;\end{array} \\
\% 28.3) \\
\text { Mean士SD }\end{array}$ & $\begin{array}{c}\text { p } \\
\text { PE- } \\
\text { Control }\end{array}$ & $\begin{array}{c}\text { p } \\
\text { Severe PE- } \\
\text { Control }\end{array}$ & $\begin{array}{c}\text { p } \\
\text { PE- } \\
\text { Severe PE }\end{array}$ & $\mathbf{p}$ \\
\hline Maternal age (year) & $31.1 \pm 6.1$ & $30.5 \pm 6.8$ & $29.9 \pm 5.8$ & 0.223 & 0.003 & 0.364 & 0.372 \\
\hline Gravida (median) & 2 & 2 & 2 & 0,191 & $<0.01$ & 0.224 & 0.010 \\
\hline Parity (median) & 1 & 0 & 1 & 0.164 & $<0.01$ & 0.081 & $<0.01$ \\
\hline Living children (median) & 1 & 0 & 1 & 0.093 & $<0.01$ & 0.134 & $<0.01$ \\
\hline Birth weight (g) & $2352 \pm 886$ & $1897 \pm 857$ & $3318 \pm 440$ & 0.001 & $<0.01$ & 0.461 & $<0.01$ \\
\hline Week of gestation at delivery & $35.0 \pm 3.3$ & $33.3 \pm 3.6$ & $38.6 \pm 0.8$ & $<0.01$ & $<0.01$ & 0.442 & $<0.01$ \\
\hline 1-minute Apgar & $7.05 \pm 1.61$ & $6.16 \pm 2.19$ & $7.67 \pm 1.22$ & 0.002 & $<0.01$ & 0.022 & $<0.01$ \\
\hline 5-minute Apgar & $8.46 \pm 1.41$ & $7.72 \pm 2.06$ & $9.18 \pm 0.88$ & $<0.01$ & $<0.01$ & 0.007 & $<0.01$ \\
\hline
\end{tabular}


Table 2. Blood count parameters of preeclamptic pregnant women and the control group.

\begin{tabular}{|c|c|c|c|c|c|c|c|}
\hline & $\begin{array}{c}\text { PE } \\
(n=190 ; \\
\% 44.0)\end{array}$ & $\begin{array}{c}\text { Severe PE } \\
(n=119 ; \\
\% 27.6)\end{array}$ & $\begin{array}{l}\text { Control } \\
(n=122 ; \\
\% 28.3)\end{array}$ & $\begin{array}{c}\text { p } \\
\text { PE- } \\
\text { Control }\end{array}$ & $\begin{array}{c}\text { p } \\
\text { Severe PE- } \\
\text { Control }\end{array}$ & $\begin{array}{c}\text { p } \\
\text { PE- } \\
\text { Severe PE }\end{array}$ & $\mathbf{p}$ \\
\hline Hemoglobin & $11.50 \pm 1.71$ & $11.63 \pm 1.53$ & $11.84 \pm 1.28$ & 0.079 & 0.111 & 0.419 & 0.100 \\
\hline Platelet & $21.6215 .79 \pm 76.593 .00$ & $194.655 .46 \pm 80.980 .48$ & $222.639 .34 \pm 60.740 .07$ & 0.001 & 0.018 & 0.570 & 0.004 \\
\hline Neutrophil & $7923.13 \pm 2963.92$ & $8893.51 \pm 4788.85$ & $7210.49 \pm 1682.06$ & 0.010 & 0.006 & 0.535 & 0.005 \\
\hline Monocyte & $692.25 \pm 312.44$ & $678.16 \pm 433.83$ & $703.44 \pm 162.54$ & 0.030 & 0.017 & 0.688 & 0.257 \\
\hline Lymphocyte & $2297.42 \pm 1492.94$ & $1986.22 \pm 792.60$ & $2071.97 \pm 53.55$ & 0.022 & 0.021 & 0.655 & 0.036 \\
\hline PLR & $111.09 \pm 59.73$ & $113.61 \pm 77.05$ & $111.18 \pm 3.11$ & 0.005 & 0.001 & 0.430 & 0.107 \\
\hline NLR & $4.28 \pm 2.99$ & $5.38 \pm 3.75$ & $3.66 \pm 1.19$ & 0.005 & 0.001 & 0.410 & 0.004 \\
\hline MLR & $0.34 \pm 0.23$ & $0.37 \pm 0.24$ & $0.36 \pm 0.10$ & 0.004 & 0.002 & 0.475 & 0.010 \\
\hline PNR & $133.17 \pm 1411.35$ & $119.70 \pm 1029.04$ & $32.37 \pm 11.26$ & 0.006 & 0.001 & 0.443 & $<0.01$ \\
\hline
\end{tabular}

$\mathrm{p}<0.01)$. Compared to the control group, delivery week was also significantly low in PE and severe PE groups $(\mathrm{p}=0.001, \mathrm{p}<0.01)$.

Blood count parameters are shown in Table 2. There was no significant difference between the groups in terms of hemoglobin values $(\mathrm{p}=0.1)$. Compared to the control group, platelet $(\mathrm{p}=0.001, \mathrm{p}=0.018)$, neutrophil $(\mathrm{p}=0.01, \mathrm{p}=0.006)$, monocyte $(\mathrm{p}=0.03, \mathrm{p}=0.017)$ and lymphocyte $(\mathrm{p}=0.022, \mathrm{p}=0.021)$ values, and PLR $(\mathrm{p}=0.005$, $\mathrm{p}=0.001)$, NLR ( $\mathrm{p}=0.005, \mathrm{p}=0.001)$, MLR ( $\mathrm{p}=0.004$, $\mathrm{p}=0.002)$ and $\mathrm{PNR}(\mathrm{p}=0.006, \mathrm{p}=0.001)$ were different in a statistically significant way in preeclampsia and severe preeclampsia groups, respectively. All these values were not statistically significant between preeclampsia and severe preeclampsia groups.

When all preeclamptic patients $(\mathrm{n}=309)$ were compared to the control group $(\mathrm{n}=122)$, the area under curve obtained for PLR is 0.435 ; when the limit value is 104.269 , it was calculated that sensitivity was $44.7 \%$, specificity was $42.6 \%$, likelihood ratio for positive test was 0.778 , positive predictive value was $72.6 \%$, likeli- hood ratio for negative test was 1.298 , and negative predictive value was $71.0 \%(\mathrm{p}=0.035)$.

The area under curve obtained for NLR is 0.548 ; when the limit value is 3.497 , it was calculated that sensitivity was $51.5 \%$, specificity was $50.8 \%$, likelihood ratio for positive test was 1.046 , positive predictive value was $71.9 \%$, likelihood ratio for negative test was 0.955 , and negative predictive value was $71.4 \%(\mathrm{p}=0.120)$.

The area under curve obtained for MLR is 0.420 ; when the limit value is 0.325 , it was calculated that sensitivity was $44.7 \%$, specificity was $44.3 \%$, likelihood ratio for positive test was 0.801 , positive predictive value was $71.9 \%$, likelihood ratio for negative test was 1.250 , and negative predictive value was $71.5 \%(\mathrm{p}=0.010)$.

The area under curve obtained for PNR is 0.394; when the limit value is 29.765 , it was calculated that sensitivity was $41.4 \%$, specificity was $42.6 \%$, likelihood ratio for positive test was 0.721 , positive predictive value was $71.1 \%$, likelihood ratio for negative test was 1.374 , and negative predictive value was $72.1 \%(\mathrm{p} \leq 0.001)$. The rates are summarized in Table 3.

Table 3. Diagnostic performance of systemic inflammatory indexes to distinguish preeclampsia from the control cases.

\begin{tabular}{|c|c|c|c|c|c|c|c|c|c|}
\hline Parameter & $\begin{array}{c}\text { AUC } \\
(95 \% \mathrm{Cl})\end{array}$ & $\mathbf{p}$ & $\begin{array}{l}\text { Limit } \\
\text { value }\end{array}$ & $\begin{array}{c}\text { Sensitivity } \\
\%\end{array}$ & $\begin{array}{c}\text { Specificity } \\
\%\end{array}$ & $\begin{array}{l}\text { LR for } \\
\text { positive } \\
\text { test }\end{array}$ & $\begin{array}{c}\text { Positive } \\
\text { predictive } \\
\text { value } \%\end{array}$ & $\begin{array}{l}\text { LR for } \\
\text { negative } \\
\text { test }\end{array}$ & $\begin{array}{c}\text { Negative } \\
\text { predictive } \\
\text { value } \%\end{array}$ \\
\hline PLR & $0.435(0.380-0.490)$ & 0.035 & 104.269 & 44.7 & 42.6 & 0.778 & 72.6 & 1.298 & 71.0 \\
\hline NLR & $0.548(0.494-0.602)$ & 0.120 & 3.497 & 51.5 & 50.8 & 1.046 & 71.9 & 0.955 & 71.4 \\
\hline MLR & $0.420(0.366-0.475)$ & 0.010 & 0.325 & 44.7 & 44.3 & 0.801 & 71.9 & 1.250 & 71.5 \\
\hline PNR & $0.394(0.340-0.449)$ & $<0.001$ & 29.765 & 41.4 & 42.6 & 0.721 & 71.1 & 1.374 & 72.1 \\
\hline
\end{tabular}

AUC: Area under curve; $95 \% \mathrm{CI}$ : 95\% confidence interval; LR: Likelihood ratio. *AUC and cut-off value were created by using ROC curve (Fig. 1). 


\section{Discussion}

Preeclampsia is a progressive disease severely compromising the health of pregnant women and fetuses. In clinical follow-up, early diagnosis may be helpful in order to prolong pregnancy, improve gestational outcomes and keep disease under control. In recent years, some maternal plasma biomarkers such as plasma placental protein 13(PP13) ${ }^{[15]}$ soluble tyrosine kinase $1(\mathrm{sFlt}-1)^{[16]}$ and placental growth factor $(\mathrm{PGF})^{[17]}$ have been defined as the markers of PE. In a study, the success rate of population screening was increased from $26 \%$ to $40 \%$ by combining PP13 with pregnancy-associated plasma protein A (PAPPA) and free leptine index. ${ }^{[15]}$ In another study, sensitivity/specificity rates of sFlt-1 and PGF to predict preeclampsia were $85 / 66 \%$ and $96 / 94 \%$, but these rates increased up to $96 / 97 \%$ when sFlt-1 and PGF were proportioned (sFlt-1/PGF) ${ }^{[18]}$ However, these biomarkers are very expensive and they still need confirmation. Simple, widespread and inexpensive laboratory findings are needed to establish the diagnosis of preeclampsia and to determine its severity. In Turkey, the parameters of complete blood count are obtained easily and their results are reached rapidly in almost all health institutions, and they are the most appropriate laboratory examination for these criteria. When hematologic parameters were evaluated, it was observed in some studies that hemoglobin values elevated, platelet numbers decreased in leukocyte numbers increased in preeclamptic pregnant women. ${ }^{[1,20]}$ Some studies asserted that the numbers of hemoglobin and thrombocyte might be associated with geographic location, dietary habits and ethnic origin. ${ }^{[21]}$ Although different results were reported in various studies, some studies reported that there was no difference between preeclamptic and healthy pregnant women in terms of hemoglobin, platelet, lymphocyte and neutrophil numbers. ${ }^{[19,22]}$ In our study, we did not find any difference between preeclampsia, severe preeclampsia and the control groups in terms of hemoglobin values but there was significant difference in preeclampsia and severe preeclampsia groups compared to the control group in terms of platelet, neutrophil, monocyte and lymphocyte values; however, there was no difference between preeclampsia and severe preeclampsia groups. When we evaluated inflammatory markers, we found a difference in preeclampsia group compared to the control group in terms of platelet/lymphocyte, platelet/neutrophil, neutrophil/lymphocyte and monocyte/lymphocyte rates but there was no difference between preeclampsia and severe preeclampsia groups. Mannaerts et al. also observed in their study that NLR increased and PLR decreased in preeclampsia group compared to the control group. ${ }^{[23]}$

Systemic inflammatory indexes are the ratio indexes considered as active markers of systemic inflammation and immune balance, and calculated by platelet, inflammatory activators (neutrophils/monocytes) and inflammatory regulators (lymphocytes) which play a significant role in diagnosis, prognosis and therapeutic evaluation of various diseases. In our study, we found that PE patients had significantly different NLR, MLR, PNR and PLR values compared to the control group and noticed that differentiated leukocyte number changed significantly in PE. Previous studies show that increased numbers of monocytes and neutrophils and surface marker activation and medium level systemic immune response in a normal pregnancy is very important to maintain a successful pregnancy. ${ }^{[24]}$ On the other hand, immune response becomes stronger in PE, it may explain clinical characteristics of PE since neutrophil and monocyte cells activated by inflammatory cytokines which are produced by placenta cells (stromal and trophoblast cells) have abnormal biological functions. ${ }^{[2]]}$ Thus, the sensitivity and specificity rates for NLR, PLR, MLR and PNR to detect preeclampsia are not even close to $95 \%$ in our study, and they are not appropriate for practical use; therefore, we concluded that they are insufficient to diagnose preeclampsia and predict the severity of the disease by using them only. However, these rates and prediction values can be increased by combining them with practical and inexpensive methods such as uterine artery Doppler.

\section{Conclusion}

Although leukocyte count is a traditional method to follow up inflammatory diseases clinically, NLR, PLR, MLR and PNR are secondary analyses to interpret the balance between inflammation and immune regulation more effectively. Our results show that NLR, PLR, MLR, PNR values as inflammation markers are more valuable than absolute leukocyte count for the early diagnosis and prognostic evaluation of PE. On the other hand, the sensitivity and specificity values of NLR, PLR, MLR, PNR indexes are not appropriate for practical use although they have advantages in terms of convenience, simplicity, sensitivity, versatility and speed, and they are insufficient alone to diagnose preeclampsia and predict their severity.

Conflicts of Interest: No conflicts declared. 


\section{References}

1. Wong TY, Groen H, Faas MM, van Pampus MG. Clinical risk factors for gestational hypertensive disorders in pregnant women at high risk for developing preeclampsia. Pregnancy Hypertens 2013;3:248-53.

2. Milosevic-Stevanovic J, Krstic M, Radovic-Janosevic D, Stefanovic M, Antic V, Djordjevic I. Preeclampsia with and without intrauterine growth restriction - two pathogenetically different entities? Hypertens Pregnancy 2016;35:57382.

3. Visser N, van Rijn BB, Rijkers GT, Franx A, Bruinse HW. Inflammatory changes in preeclampsia: current understanding of the maternal innate and adaptive immune response. Obstet Gynecol Surv 2007;62:191-201.

4. Laresgoiti-Servitje E, Gómez-López N, Olson DM. An immunological insight into the origins of pre-eclampsia. Hum Reprod Update 2010;16:510-24.

5. Laresgoiti-Servitje E. A leading role for the immune system in the pathophysiology of preeclampsia. J Leukoc Biol 2013; 94:247-57.

6. Gu Y, Lewis DF, Deere K, Groome LJ, Wang Y. Elevated maternal IL-16 levels, enhanced IL-16 expressions in endothelium and leukocytes, and increased IL-16 production by placental trophoblasts in women with preeclampsia. J Immunol 2008;181:4418-22.

7. Taylor RN, Roberts JM. Endothelial cell dysfunction. In: Lindheimer MD, Roberts JM, Cunningham FG, editors. Hypertensive disorders in pregnancy. 2nd ed. Stamford, CT: Appleton \& Lange; 1999. p. 395-429.

8. Celikbilek M, Dogan S, Ozbakır O, Zararsız G, Kücük H, Gürsoy S, et al. Neutrophil-lymphocyte ratio as a predictor of disease severity in ulcerative colitis. J Clin Lab Anal 2013;27:72-6.

9. Imtiaz F, Shafique K, Mirza SS, Ayoob Z, Vart P, Rao S. Neutrophil lymphocyte ratio as a measure of systemic inflammation in prevalent chronic diseases in Asian population. Int Arch Med 2012;5:2.

10. Tousoulis D, Antoniades C, Koumallos N, Stefanadis C. Pro-inflammatory cytokines in acute coronary syndromes: from bench to bedside. Cytokine Growth Factor Rev 2006; $17: 225-33$.

11. Zahorec R. Ratio of neutrophil to lymphocyte counts Rapid and simple parameter of systemic inflammation and stress in critically ill. Bratisl Lek Listy 2001;102:5-14.

12. Proctor MJ, Morrison DS, Talwar D, Balmer SM, Fletcher CD, O'Reilly DS, et al. A comparison of inflammation-based prognostic scores in patients with cancer. A Glasgow Inflammation Outcome Study. Eur J Cancer 2011;47:263341.

13. Elgari MM, Khabour OF, Alhag SM. Correlations between changes in hematological indices of mothers with preeclamp- sia and umbilical cord blood of newborns. Clin Exp Hypertens 2018;41:58-61.

14. American College of Obstetricians and Gynecologists; Task Force on Hypertension in Pregnancy. Hypertension in pregnancy. Report of the American College of Obstetricians and Gynecologists' Task Force on Hypertension in Pregnancy. Obstet Gynecol 2013;122:1122-31.

15. De Villiers CP, Hedley PL, Placing S, Wøjdemann KR, Shalmi AC, Carlsen AL, et al. Placental protein-13 (PP13) in combination with PAPP-A and free leptin index (fLI) in first trimester maternal serum screening for severe and early preeclampsia. Clin Chem Lab Med 2017;56: 65-74.

16. Burke SD, Zsengellér ZK, Khankin EV, Lo AS, Rajakumar A, DuPont JJ, et al. Soluble fms-like tyrosine kinase 1 promotes angiotensin II sensitivity in preeclampsia. J Clin Invest 2016;126:2561-74.

17. Lecarpentier É, Vieillefosse S, Haddad B, Fournier T, Leguy $\mathrm{MC}$, Guibourdenche J, et al. Placental growth factor (PlGF) and sFlt-1 during pregnancy: physiology, assay and interest in preeclampsia. Ann Biol Clin (Paris) 2016;74:259- 67.

18. Taraseviãienò V, Grybauskienò $\mathrm{R}$, Maãiuleviãienò R. sFlt-1, PlGF, sFlt-1/PlGF ratio and uterine artery Doppler for preeclampsia diagnostics. Medicina (Kaunas) 2016;52:349-53.

19. Canzoneri BJ, Lewis DF, Groome L, Wang Y. Increased neutrophil numbers account for leukocytosis in women with preeclampsia. Am J Perinatol 2009;26:729-32.

20. Yavuzcan A, Cağlar M, Ustün Y, Dilbaz S, Ozdemir I, Yildiz $\mathrm{E}$, et al. Mean platelet volume, neutrophil-lymphocyte ratio and platelet-lymphocyteratio in severe preeclampsia. Ginekol Pol 2014;85:197-203.

21. Järemo P, Lindahl TL, Lennmarken C, Forsgren H. The use of platelet density and volume measurements to estimate the severity of pre-eclampsia. Eur J Clin Invest 2000;30: 1113-8.

22. Ramma $W$, Buhimschi IA, Zhao G, Dulay AT, Nayeri UA, Buhimschi CS, et al. The elevation in circulating anti-angiogenic factors is independent of markers of neutrophil activation in preeclampsia. Angiogenesis 2012;15:333-40.

23. Mannaerts D, Heyvaert S, De Cordt C, Macken C, Loos C, Jacquemyn Y. Are neutrophil/lymphocyte ratio (NLR), platelet/lymphocyte ratio (PLR), and/or mean platelet volume (MPV) clinically useful as predictive parameters for preeclampsia? J Matern Fetal Neonatal Med 2019;32:1412-9.

24. Palm M, Axelsson O, Wernroth L, Larsson A, Basu S. Involvement of inflammation in normal pregnancy. Acta Obstet Gynecol Scand 2013;92:601-5.

25. Germain SJ, Sacks GP, Sooranna SR, Sargent IL, Redman CW. Systemic inflammatory priming in normal pregnancy and preeclampsia: the role of circulating syncytiotrophoblast microparticles. J Immunol 2007;178:5949-96. 